\title{
Maternal obesity and late effects on offspring metabolism
}

\section{Obesidade materna e efeitos tardios sobre o metabolismo da prole}

Daniele Sá Vido, Mariana Bocca Nejm', Neila Ribeiro Silva', Sylvia

Maria Affonso Silva', Sérgio Luiz Cravo', Jacqueline Luz'

\begin{abstract}
Objective: The aim of this study was to evaluate the late effects of maternal obesity induced by lesion of the ventromedial hypothalamus on offspring metabolism. Materials and methods: Thirty days after the bilateral lesion of the ventromedial hypothalamus, female rats were mated and divided into 2 groups of pregnant animals: Control (C) - false lesion (sham) and Obese (OB) - lesion. Three months after that, with the groups of mothers, offspring were divided into control and obese animals that received a normocaloric diet (C-N and OB-N), and control and obese animals that received a hypercaloric diet (C-H and OB-H). At 120 days of age, the animals were euthanized and their carcasses, feces and food were submitted to calorimetric analysis to determine energy balance and body composition. Results: During the growth period, offspring from obese mothers showed higher values of body weight and food intake than controls. Obese animals showed higher body weight gain and gross food efficiency than control animals in adulthood. The hypercaloric diet led to increased metabolizable energy intake, percentage of absorbed energy and energy expenditure in both groups. Body composition was only affected by the association of hypercaloric diet and maternal obesity that led to increased body fat. Conclusions: Maternal obesity has led to the development of later overweight in offspring, suggesting fetal programming. According to the trend presented, it is believed that the prolonged intake of hypercaloric diets in adult animals may, as an additional effect, induce worsening of the overweight induced by maternal obesity. Arq Bras Endocrinol Metab. 2014;58(3):301-7
\end{abstract}

\section{Keywords}

Fetal programming; obesity; energy metabolism; body composition; hypercaloric diet

\section{RESUMO}

Objetivo: Avaliar os efeitos tardios da obesidade materna induzida por lesão do núcleo ventromedial do hipotálamo sobre o metabolismo da prole. Materiais e métodos: Trinta dias após a lesão bilateral do hipotálamo ventromedial, ratos fêmeas foram colocadas para acasalar e divididas em dois grupos de animais gestantes: Controle $(C)$ - falsa lesão e Obeso (OB) - lesionados. Três meses após o nascimento, de acordo com os grupos das mães, os filhotes foram divididos em animais controle e obesos que recebiam dieta normocalórica (C-N and OB-N) e animais controle e obesos que recebiam dieta hipercalórica ( $\mathrm{C}-\mathrm{H}$ and $\mathrm{OB}-\mathrm{H}$ ). Aos 120 dias de idade, os animais foram eutanasiados e as carcaças, fezes e ração foram submetidas à análise calorimétrica para determinação do balanço energético e composição corporal. Resultados: Durante o período de crescimento, os filhos de mães obesas mostraram maiores valores de peso corporal e ingestão alimentar que animais controle. Os animais obesos apresentaram maiores valores de ganho de peso corporal e eficiência metabólica que os animais controle quando adultos. A dieta hipercalórica levou ao aumento da energia metabolizável, percentagem de energia absorvida e gasto energético para ambos os grupos. A composição corporal foi somente afetada pela associação da dieta hipercalórica com a obesidade materna que levou ao aumento da gordura corporal. Conclusões: A obesidade materna levou ao sobrepeso tardio na prole, sugerindo uma programação fetal. Pela tendência apresentada, acreditamos que a ingestão prolongada de dietas hipercalóricas em animais adultos possa induzir uma piora no quadro de sobrepeso induzido pela obesidade materna. Arq Bras Endocrinol Metab. 2014;58(3):301-7

\section{Descritores}

Programação fetal; obesidade; metabolismo energético; composição corporal; dieta hipercalórica
'Department of Physiology, Universidade Federal de São Paulo, São Paulo, Brazil

Correspondence to:

Jacqueline Luz

Departamento de Fisiologia

Universidade Federal de São Paulo

Rua Botucatu, 862, $5^{\circ}$ andar

04023-062 - São Paulo, SP, Brazil

jluz@unifesp.br

Received on Oct/2/2013 Accepted on Feb/20/2014 


\section{INTRODUCTION}

$\mathrm{O}$ besity is a worldwide epidemic, independent of economic or social conditions. Besides representing a problem in developed countries, overweight and obesity are dramatically increased in the population of low- and middle income, especially in urban areas $(1,2)$. The increasing rate of obesity among children and adolescents is particularly alarming, and the factors contributing to this situation are probably the sedentary lifestyle and dietary changes, especially in individuals who already have a tendency to obesity $(3,4)$. Thus, the overall increase in overweight and obesity naturally leads to a disturbing increase in the incidence of obesity in pregnant women.

Obesity and/or overweight have a major impact on the health of both mother and offspring. Studies suggest that changes in the intrauterine environment of obese women can cause metabolic adaptations in the fetuses, with immediate or late consequences $(1,5)$.

Maternal exposure to obesity during pregnancy, even in the absence of diabetes, can have negative consequences to the offspring (6). Maternal obesity is associated with 2 -fold higher incidence of heavier newborns than in non-obese women (7).

Shields and cols. (8) demonstrated a direct relationship between maternal body composition and offspring adiposity, and suggested that offspring body fat is associated with maternal fat, but not with paternal fat mass.

Catalano and cols. (9) demonstrated that fetuses of obese mothers have higher percentage of body fat than fetuses of lean mothers. According to Catalano and Ehrenberg (10) pre-pregnancy and gestational obesity can lead to macrosomia due to increased adiposity and not lean body mass $(11,12)$.

Shankar and cols. (13) suggest that maternal obesity may be responsible for fetal programming, resulting in later obesity. Different effects resulting from maternal obesity can be observed in adulthood (14).

Maternal obesity has no influence on body weight of offspring, similar to the effect of high-fat diet during pregnancy, suggesting that maternal adiposity, per se, is necessary for the programming effect that predisposes the offspring to obesity (15).

Adequate postnatal nutrition can reduce the factors that lead to obesity in the offspring, while the high-fat nutrition can enhance the development of obesity and metabolic syndrome (16).

Recently, we have found no significant changes in body weight and body composition of rat fetuses from obese mothers, with obesity induced by electrolytic lesion of the ventromedial hypothalamus nucleus (VMH) (unpublished data). Thus, the objective of this study was to assess the late effects of maternal obesity induced by $\mathrm{VMH}$ lesion on energy balance and body composition of offspring fed normo- and hypercaloric diets.

\section{MATERIALS AND METHODS}

\section{Animals and experimental design}

All procedures and methods used on the experimental animals were examined and approved by the ethics committee of the Universidade Federal de São Paulo (Unifesp-EPM) (\#0217/09), and the animals were cared for in accordance with the Guide to the Care and Use of Experimental Animals.

During the experimental period, the animals were kept in room at controlled constant temperature $(23$ $\pm 1^{\circ} \mathrm{C}$ ) on light-dark cycle (lights turned on at $7 \mathrm{am}$ ).

Female rats Wistar EPM-1, 60 days of age, underwent stereotactic surgery to induce obesity by an electrolytic lesion of the ventromedial hypothalamic neurons responsible for the control of satiety (17). Animals were anesthetized by inhalation with halothane and electrodes were introduced in the ventromedial hypothalamus at the following coordinates: $2.5 \mathrm{~mm}$ posterior to Bregma, $0.5 \mathrm{~mm}$ lateral to Bregma, 9.5 $\mathrm{mm}$ ventral to the dorsal surface. The intensity of the stimulus for neuronal injury was $1 \mathrm{~mA}$ for 30 seconds. Coordinates were taken from the stereotaxic atlas (18) and adapted to the size of the female rats. After this step was standardized, the coordinates were histologically confirmed by electronic microscopy using rat brain sections on glass slides. Ten days after the lesion, rats were euthanized by decapitation and their brains removed and stored in a freezer at $-80^{\circ} \mathrm{C}$ to be sectioned later on in a cryostat $\left(-20^{\circ} \mathrm{C}\right)$ to confirm the lesion. Control animals were submitted to false lesions (sham) meaning the same procedure without stimulation after insertion of the electrodes at the same determined points.

After surgery, animals received water and food $a d$ libitum, with the water containing analgesic solution for 2 days. Their food intake and body weight were monitored for 30 days (experimental period) and used as physiological parameters in order to establish the efficacy of the lesion. On the $30^{\text {th }}$ day after surgery, female rats were placed with adult males for mating, and the day of pregnancy was determined by the presence of sperm in a vaginal smear. 
Throughout the gestational period, pregnant rats were kept in individual metabolic cages and divided into two main groups: Control $(\mathrm{C})$ - animals with false hypothalamic lesion (sham) and Obese (OB) - animals with hypothalamic lesion.

After birth by spontaneous delivery, only 6 newborn females were kept with their mothers in order to prevent nutritional differences. When the number of females was not sufficient, males were used to complete the group of six offspring, but they were discarded at weaning (28 days after birth). The animals had free access to food and water during the lactation period. From weaning until the $2^{\text {nd }}$ month of life $\left(28^{\text {th }}-60^{\text {th }}\right.$ of age $)$, all animals had their food intake and body weight measured.

In the last month $\left(60^{\text {th }}-90^{\text {th }}\right.$ days of age $), 2$ groups were formed for each state (control or obese), including the normocaloric and hypercaloric diets, which subsequently were re-divided into 4 groups: offspring of control and obese mothers that received normocaloric diets (C-N and OB-N, respectively), and offspring of control and obese mothers that received hypercaloric $\operatorname{diet}(\mathrm{C}-\mathrm{H}$ and $\mathrm{OB}-\mathrm{H}$, respectively).

The standard food (CR-1 Nuvilab, Brazil, 22\% protein, $4.5 \%$ fat, $55 \%$ carbohydrate, $7 \%$ fiber) was used for normocaloric diet, while the hypercaloric diet (palatable diet) was composed of $20 \%$ protein, $20 \%$ fat, $40 \%$ carbohydrate and $4 \%$ fiber. A palatable hypercaloric diet consisted of standard food (CR-1 Nuvilab, Brazil) plus peanuts, chocolate and sweets biscuits in the ratio of 3:2:1. All components were powdered, mixed and dried at $60^{\circ} \mathrm{C}$ for 2 days (19).

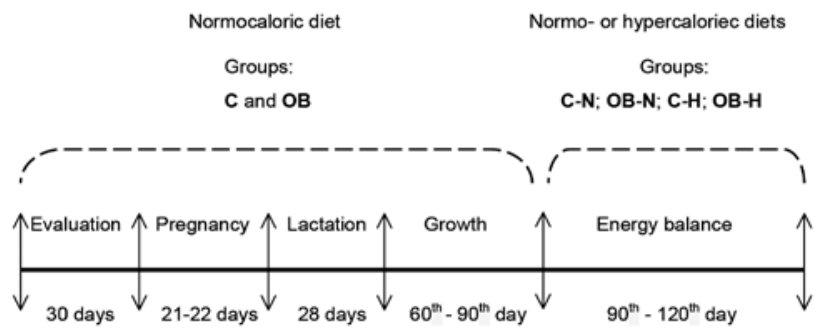

Figure 1. Schematic summary of the experimental protocol.

\section{Energy balance}

The energy balance was determined in a 30 -day period (from the $90^{\text {th }}$ to $120^{\text {th }}$ days).

On the $120^{\text {th }}$ day, animals were anesthetized with sodium pentobarbital $(60 \mathrm{mg} / \mathrm{kg}$, intraperitoneally), and euthanized by decapitation. After animals were killed, the abdominal cavity was opened, and the guts removed, emptied and put back in the carcass. The carcass was weighed (fresh weight) and homogenized in a blender with an equal volume of water after the hard tissues were softened. Homogenate samples were collected to determine the protein and lipid content. The homogenized material was dried at $60^{\circ} \mathrm{C}$ until weight stabilization (dry weight), and the resultant material was re-homogenized. Water percentage was obtained from the difference between fresh weight and dry weight of the carcasses. Samples were used to determine the energy content in an adiabatic calorimeter (IKA C-5000). Throughout the period, feces were collected and dried the same way and, after that, the energy content was determined. Body weight and food intake were measured daily, and samples of feed pellets were analyzed repeatedly in a calorimeter for energy content $(\mathrm{kJ})$ per gram of chow. Energy intake was calculated by multiplying the total amount ingested $(\mathrm{g})$ by the food energy content $(16.36 \mathrm{~kJ} / \mathrm{g}$ for the normocaloric diet, and $21.33 \mathrm{~kJ} / \mathrm{g}$ for hypercaloric diet). Thus, the energy balance parameters were calculated as follows:

Energy intake (kJ) = amount of feed ingested (g) X energy content in the diet

Absorbed Energy $(\mathrm{kJ})=$ energy intake - energy in feces

Percentage of absorbed energy $(\%)=$ absorbed energy $\times 100$ energy intake

Metabolizable energy intake $(\mathrm{kJ})=96 \%$ absorbed energy (20)

Body weight gain = final body weight $\left(120^{\text {th }}\right.$ day $)$ - initial body weight $\left(90^{\text {th }}\right.$ day $)$

Body energy gain $(\mathrm{KJ})=$ final body energy $\left(120^{\text {th }}\right.$ day) - initial body energy $\left(90^{\text {th }}\right.$ day). Body energy gain was determined from the groups of animals killed on the $90^{\text {th }}$ day of the experiment for each treatment (control; $n=18$ and obese; $n=18$ ). Regression of body weight vs body energy was calculated. The initial body energy of the experimental animals was calculated from their initial body weight using the previously calculated regression equation.

Energy expenditure $(\mathrm{kJ})=$ metabolizable energy intake - body energy gain

Gross food efficiency $(\%)=\quad$ energy gain $\quad \times 100$

metabolizable energy intake

Percentage of water in the carcass $(\%)=$ fresh weight - dry weight $X 100$

fresh weight

\section{Body composition}

Carcass fat and protein contents were determined in fresh samples of homogenized carcasses using the chloroformmethanol (21) and the Lowry (22) methods, respectively.

\section{Statistical analysis}

Statistical analysis was performed using the unpaired Student's $t$ test for two-independent groups, or oneway ANOVA followed by the Tukey's post-hoc test. The significance level to reject the null hypothesis was 
5\%. All analyses were performed using the statistical software GraphPad Prizm (GraphPad Software, version 5.01 San Diego, CA, USA).

\section{RESULTS}

Table 1 shows the values of body weight gain and total food intake of control and obese animals during the pregnancy and lactation periods. Both parameters increased in obese animals $(\mathrm{p}<0.05)$, following the experi- mental VMH lesion (evaluation period). There was no significant difference between groups $(\mathrm{p}>0.05)$, during pregnancy and lactation, except for increased food intake shown by obese animals during pregnancy $(\mathrm{p}<0.05)$.

Despite the trend of the obese pups compared with their respective controls during the lactation period, no significant differences were found for body weight $(\mathrm{p}>$ $0.05)$ (Figure 1A). However, these differences became evident in the growth period $\left(30^{\text {th }}-60^{\text {th }}\right.$ days $)(\mathrm{p}<$ 0.05 ) (Figure 1B).

Table 1. Body weight gain $(\mathrm{g})$ and total food intake $(\mathrm{g})$ of control $(\mathrm{C})$ and obese $(\mathrm{OB})$ animals during the evaluation period (30 days after surgery), pregnancy (21-22 days) and lactation (28 days). Values represent means \pm SEM. Numbers of observations $(\mathrm{n})$ in parenthesis

\begin{tabular}{|c|c|c|c|c|}
\hline \multirow{2}{*}{ Period } & \multicolumn{2}{|c|}{ Body weight gain (g) } & \multicolumn{2}{|c|}{ Total food intake (g) } \\
\hline & C & OB & C & OB \\
\hline Evaluation & $32.00 \pm 1.82(12)$ & $65.20 \pm 3.81^{*}(10)$ & $445.69 \pm 8.38(12)$ & $557.44 \pm 15.96^{*}(10)$ \\
\hline Pregnancy & $110.00 \pm 8.94(7)$ & $121.60 \pm 7.86$ & $436.57 \pm 18.64(7)$ & $546.70 \pm 24.66^{*}(5)$ \\
\hline Lactation & $-37.14 \pm 9.55(7)$ & $-41.20 \pm 8.96(5)$ & $1204.25 \pm 54.83(7)$ & $1337.71 \pm 92.93$ \\
\hline
\end{tabular}

*vs. C; $p<0.05$.

A
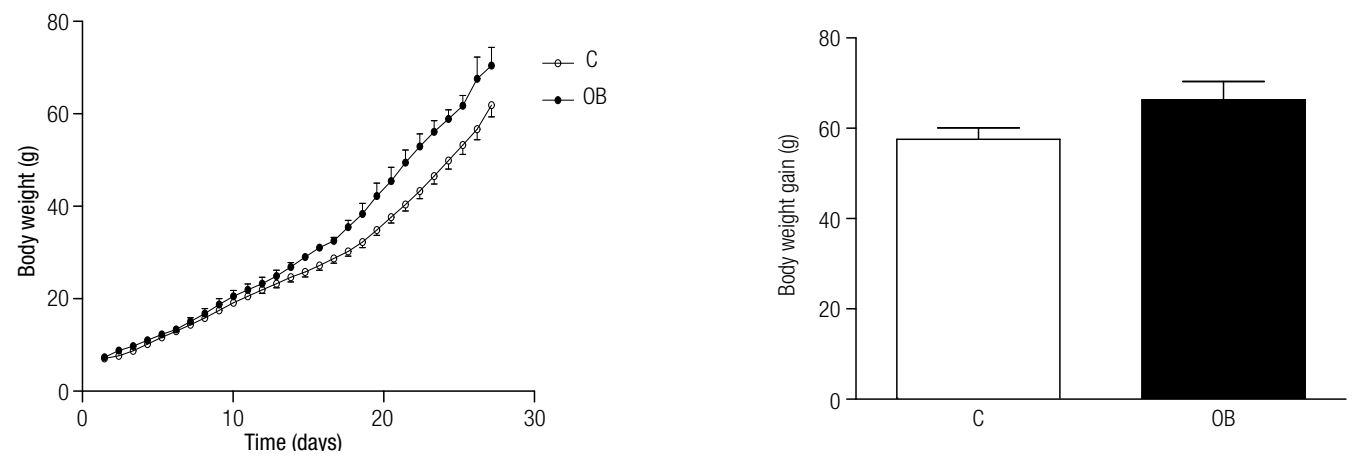

B
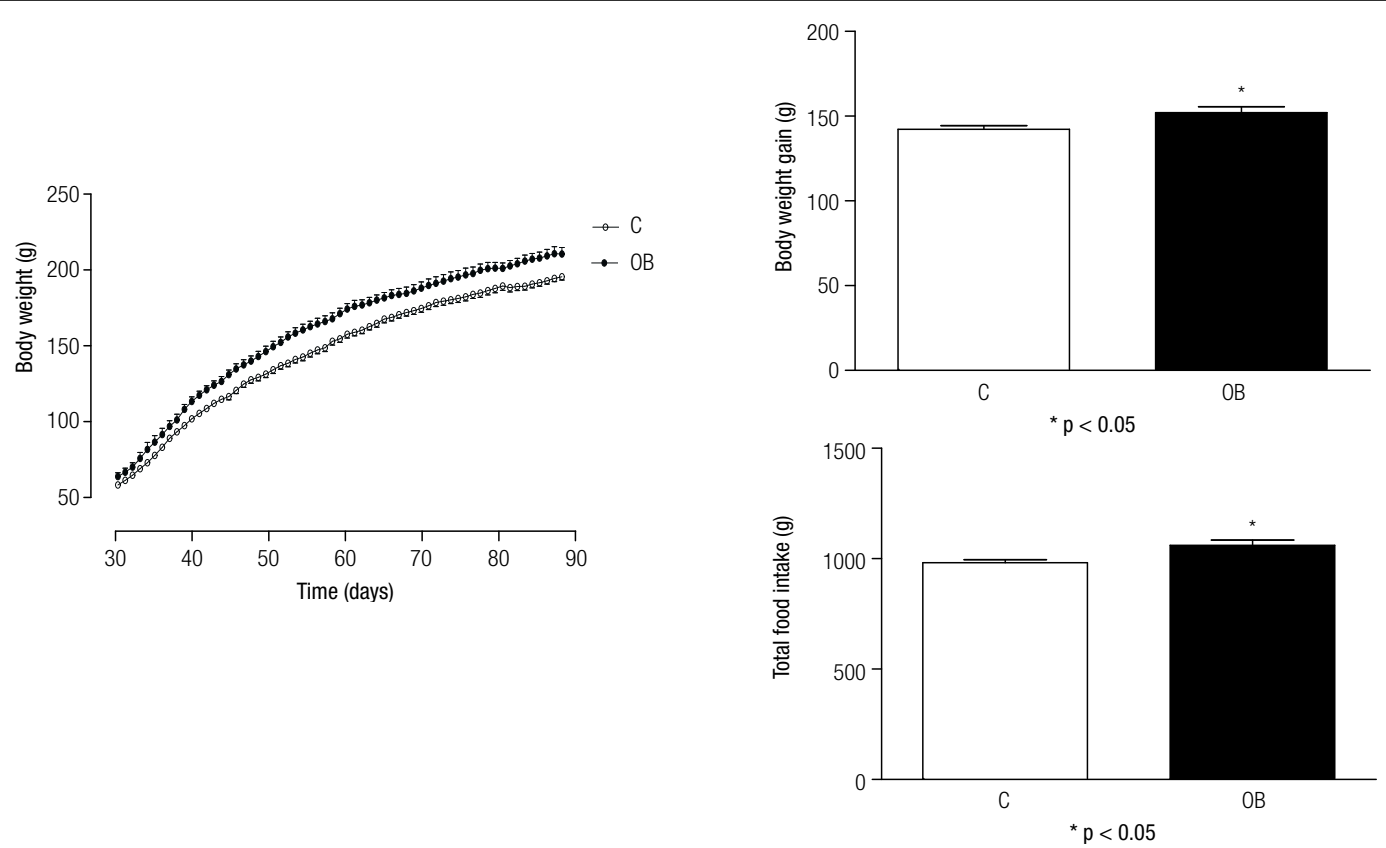

Figure 1. (A) Body weight $(\mathrm{g})$ and body weight gain $(\mathrm{g})$ of control $(\mathrm{C})$ and obese $(\mathrm{OB})$ animals during lactation $\left(0-28^{\text {th }}\right.$ day). (B) Body weight $(\mathrm{g})$, body weight gain $(\mathrm{g})$, and total food intake $(\mathrm{g})$ of control $(\mathrm{C})$ and obese $(\mathrm{OB})$ animals during the growth period $\left(30^{\text {th }}-60^{\text {th }}\right.$ day). Each point and bar represents the mean \pm SEM. * $v$ s. C. $p<0.05$. 
Table 2 shows the energy balance, gross food efficiency and absorbed energy values determined in control and obese animals fed the normo- $(\mathrm{N})$ and hypercaloric $(\mathrm{H})$ diets for 30 days $\left(90^{\text {th }}-120^{\text {th }}\right)$. Obese animals showed lower percentage of absorbed energy and higher body weight gain and gross metabolic efficiency than control animals $(\mathrm{p}<0.05)$. The hypercaloric diet led to increased metabolizable energy intake, percentage of absorbed energy and energy expenditure for both groups of animal control and obese, when compared with normocaloric animals $(\mathrm{p}<0.05)$.

Body composition (Table 3 ) was not affected by maternal obesity, except for a decrease in water content $(\mathrm{p}<0.05)$, which was also affected by the hypercaloric diet in both control and obese groups. Both maternal obesity and the hypercaloric diet were not able to significantly change the body fat content ( $p>0.05$ ); however, the combination of both factors led to an effective increase in adiposity of these animals $(\mathrm{p}<0.05)$. The protein content was not affected by maternal obesity or the hypercaloric diet $(\mathrm{p}>0.05)$.

\section{DISCUSSION}

The electrolytic lesion in the ventromedial nucleus of the hypothalamus (VMH) is widely described in the literature as an animal model of obesity and hyperphagia, followed by increased body weight, as the main charac- teristic of this model, besides the increase in fat stores (17). As expected, during the first 30 days after surgery (evaluation period), the animals with lesions exhibited an increase of about $25 \%$ in food intake, and more than twice the body weight gain compared with their respective controls. Therefore, they were considered obese. Goldman and cols. (23) reported that VMH lesions led to increased weight gain by increasing fat deposits, primarily caused by adipocyte hypertrophy. Corroborating these findings, we recently found in our laboratory (unpublished data) that carcasses of obese animals have approximately $78 \%$ more fat than the control group.

During the period of pregnancy, obese animals maintained their food intake and body weight above the control animals. Body weight gain was similar between control and obese groups, suggesting that obesity did not alter the pattern of body weight for the gestational period (24). Similarly, there was no difference between groups during the lactation period, in which a reduction in body weight is expected due to the high demand for milk production (24).

The literature is controversial regarding the effects of maternal obesity on offspring birth weight. Hull and cols. (12) found that neonates born to overweight/ obese mothers have a fat mass to fat-free mass ratio significantly higher than neonates born to mothers with normal body weight. On the other hand, Shankar and cols. (13) reported that the number of newborns, the

Table 2. Parameters of energy balance ( $\mathrm{kJ} / 30$ days), gross food efficiency, and absorbed energy in control $(\mathrm{C})$ and obese $(\mathrm{OB})$ animals fed normo- $(\mathrm{N})$ and hypercaloric $(\mathrm{H})$ diets for 30 days $\left(90^{\text {th }}-120^{\text {th }}\right.$ days). Values represent means \pm SEM. Numbers of observations $(n)$ in parenthesis

\begin{tabular}{|c|c|c|c|c|}
\hline & \multicolumn{2}{|c|}{ Normocaloric } & \multicolumn{2}{|c|}{ Hypercaloric } \\
\hline & $\begin{array}{c}C-N \\
(n=10)\end{array}$ & $\begin{array}{c}\text { OB-N } \\
(n=10)\end{array}$ & $\begin{array}{c}\text { C-H } \\
(n=9)\end{array}$ & $\begin{array}{c}\text { OB-H } \\
(n=10)\end{array}$ \\
\hline BWG (g) & $18.80 \pm 2.41$ & $29.56 \pm 3.07^{\star}$ & $27.00 \pm 2.83$ & $33,20 \pm 2.22^{*}$ \\
\hline MEI (kJ) & $5135,41 \pm 142.04$ & $5140.09 \pm 180.77$ & $7491.19 \pm 378.20^{\star \circ}$ & $7530.08 \pm 252.88^{* \circ}$ \\
\hline AEN (\%) & $76.22 \pm 0.92$ & $73.61 \pm 0.37^{\star}$ & $87.29 \pm 0.45^{\star \circ}$ & $88.07 \pm 0.56^{\star 0}$ \\
\hline $\mathrm{EG}(\mathrm{kJ})$ & $270.37 \pm 30.58$ & $508.39 \pm 47.15$ & $675.57 \pm 86.78^{\star}$ & $719.91 \pm 89.03^{*}$ \\
\hline $\mathrm{EE}(\mathrm{kJ})$ & $4865.04 \pm 159.06$ & $4631.70 \pm 157.57$ & $6816.62 \pm 348.26^{\star \circ}$ & $6810.17 \pm 191.72^{\star \circ}$ \\
\hline GFE $(\%)$ & $5.38 \pm 0.66$ & $9.85 \pm 0.74^{*}$ & $9.00 \pm 1.03^{*}$ & $9.39 \pm 0.98^{\star}$ \\
\hline
\end{tabular}

BWG: body weight gain; MEl: metabolizable energy intake; AEN: absorbed energy; EG: energy gain; EE: energy expenditure; GFE: gross food efficiency.

${ }^{*}$ vs. C-N; ${ }^{\circ}$ vs. OB-N. p $<0.05$.

Table 3. Body composition in control $(\mathrm{C})$ and obese $(\mathrm{OB})$ animals fed normo- $(\mathrm{N})$ and hypercaloric $(\mathrm{H})$ diets for 30 -days $\left(90^{\text {th }}-120^{\text {th }}\right.$ days). Values represent means \pm SEM. Numbers of observations $(n)$ in parenthesis

\begin{tabular}{|c|c|c|c|c|}
\hline & \multicolumn{2}{|c|}{ Normocaloric } & \multicolumn{2}{|c|}{ Hypercaloric } \\
\hline & $\begin{array}{c}C-N \\
(n=10)\end{array}$ & $\begin{array}{c}\text { OB-N } \\
(n=10)\end{array}$ & $\begin{array}{c}\text { C-H } \\
(n=9)\end{array}$ & $\begin{array}{c}\text { OB-H } \\
(n=10)\end{array}$ \\
\hline Protein $(\mathrm{mg} / \mathrm{g})$ & $186.96 \pm 9.78$ & $186.47 \pm 7.16$ & $169.08 \pm 6.64$ & $175.86 \pm 8.01$ \\
\hline Fat $(\mathrm{mg} / \mathrm{g})$ & $193.53 \pm 9.52$ & $214.85 \pm 5.36$ & $210.57 \pm 3.72$ & $231.53 \pm 9.13^{*}$ \\
\hline Water (\%) & $61.53 \pm 0.53$ & $59.40 \pm 0.01^{*}$ & $59.02 \pm 0.01^{*}$ & $57.81 \pm 0.01^{\star \circ}$ \\
\hline
\end{tabular}

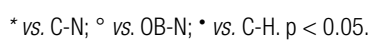


birth weight and birth size were not affected by maternal obesity. Similar results were reported by Mingrone and cols. (25).

Several authors have suggested that maternal obesity can lead to different early (26) and later effects in adults (14) as results of a possible fetal programming (13).

In the present study, newborns from the obese and control groups showed no differences for body weight from birth to weaning $\left(0-28^{\text {th }}\right.$ days $)$, despite the slight trend for increased body weight gain in obese animals. In fact, obese animals showed significant increase in food intake and body weight gain during the growth period $\left(30^{\text {th }}-60^{\text {th }}\right.$ days $)$. Bayol and cols. (27) reported that the increased food intake precedes the increased body weight in the offspring of obese mothers, suggesting that this excessive intake is an obesity-inducing factor in these animals. In adulthood $\left(90^{\text {th }}-120^{\text {th }}\right.$ days), body weight gain remains high, despite food intake stabilization, probably due to the high food efficiency presented by these animals. Different studies have shown that maternal overnutrition interferes with offspring adiposity and appetite brain markers $(28,29)$. Muhlhausler and cols. (30) suggest that the fetuses have a central appetite-regulating neural network able to respond to changes in nutrient supply, which could have an impact on energy balance both before and after birth.

The hypercaloric diet not only induced the increased weight gain and metabolizable energy intake, but also the energy gain of both groups, as previously reported by Iossa and cols. (31). The percentage of absorbed energy was affected by the diet, probably due to the increased permeability of the small intestine induced by the high-fat diet intake (32).

Despite the trend in increased energy gain presented by obese animals, the energy gain and energy expenditure were not significantly affected by maternal obesity, but both were increased by the hypercaloric diet. The increased energy gain presented is naturally expected from increased fat deposits, which is especially proven in obese animals. On the other hand, the increased energy expenditure is probably due to diet-induced thermogenesis that occurs to limit the excess energy stored in rats overfed palatable diets, according to the classic study of Rothwell and Stock (33). Iossa and cols. (31), working with adult rats submitted to high-fat diet for 2 weeks, found similar results for energy balance.

Jéquier (34) suggested that the efficiency of nutrient utilization is higher for fat than for carbohydrate or protein; therefore, high-fat diet tends to increase energy efficiency. In fact, gross food efficiency was increased in both groups (hypercaloric diet and maternal obesity), which may explain the increased body weight gain shown by the obese animals.

Both maternal obesity and the diet did not lead to a significant increase in body fat, but their combination effectively increased body fat content and, consequently, reduced the water percentage in the carcass. The increase in fat deposits naturally leads to water content reduction, as observed in obese animals previously described by Chlouverakis and cols. (35). As expected, the protein content was not altered by maternal obesity or the hypercaloric diet.

These results demonstrate that maternal obesity induced by VMH lesions led to changes in the pattern of food control and late development of overweight in the offspring, suggesting fetal programming. The hypercaloric diet imposed in adulthood increased body fat, but did not change the overweight induced by maternal obesity. Therefore, according to the aforementioned trends, it is believed that prolonged intake of this diet can lead to worsening of the overweight presented by these animals, as an extra effect.

Acknowledgements: Daniele Sá Vido had a graduate student scholarship from the Coordenação de Aperfeiçoamento de Pessoal de Nível Superior (Capes).

Disclosure: no potential conflict of interest relevant to this article was reported.

\section{REFERENCES}

1. Nelson SM, Mathews P, Poston L. Maternal metabolism and obesity: modifiable determinants of pregnancy outcome. Hum Reprod Update. 2010;16:255-75.

2. Han JC, Lawlor DA, Kimm SYS. Childhood obesity. The Lancet. 2010;375:1737-48.

3. Hill JO, Peters JC. Environmental contributions to the obesity epidemic. Science. 1998;280:1371-4.

4. Swinburn BA, Caterson I, Seidell JC, James WP. Diet, nutrition and the prevention of excess weight gain and obesity. Public Haelthh Nutr. 2004;7:123-46.

5. King JC. Maternal obesity, metabolism, and pregnancy outcomes. Annu Rev Nutr. 2006;26:271-91.

6. Knight B, Shields BM, Hill A, Powell RJ, Wright D, Hattersley AT. The impact of maternal glycemia and obesity on early postnatal growth in a nondiabetic Caucasian population. Diabetes Care. 2007;30:777-83.

7. Castro LC, Avina RL. Maternal obesity and pregnancy outcomes. Curr Opin Obstet Gynecol. 2002;14:601-6.

8. Shields BM, Knight BA, Powell RJ, Hattersley AT, Wright DE. Assessing newborn body composition using principal com- 
ponents analysis: differences in the determinants of fat and skeletal size. BMC Pediatr. 2006;6:24.

9. Catalano PM, Presley L, J, Hauguel-de Mouzon S. Fetuses of obese mothers develop insulin resistance in utero. Diabetes Care. 2009;32:1076-80b.

10. Catalano PM, Ehrenberg HM. The short- and long-term implications of maternal obesity on the mother and her offspring. BJOG. 2006;113:1126-33.

11. Sewell MF, Huston-Presley L, Super DM, Catalano P. Increased neonatal fat mass, not lean body mass, is associated with maternal obesity. Am J Obstet Gynecol. 2006;195:1100-3.

12. Hull HR, Dinger MK, Knehans AW, Thompson DM, Fields DA. Impact of maternal body mass index on neonate birthweight and body composition. Am J Obstet Gynecol. 2008;9:416. e411-16.

13. Shankar K, Harrell A, Liu X, Gilchrist JM, Ronis MJ, Badger TM. Maternal obesity at conception programs obesity in the offspring. Am J Physiol Regul Integr Comp Physiol. 2008;294:R526-38.

14. Mamun AA, O'Callaghan M, Callaway L, Williams G, Najman J, Lawlor DA. Associations of gestational weight gain with offspring body mass index and blood pressure at 21 years of age: evidence from a birth cohort study. Circulation. 2009;119:1720-7.

15. White $C L$, Purpera MN, Morrison CD. Maternal obesity is necessary for programming effect of high-fat diet on offspring. Am J Physiol Regul Integr Comp Physiol. 2009;296:R1464-72.

16. Levin BE. Metabolic imprinting: critical impact of the perinatal environment on the regulation of energy homeostasis. Phil Trans R Soc B. 2006;361:1107-21.

17. King BM. The rise, fall, and resurrection of the ventromedial hypothalamus in the regulation of feeding behavior and body weight. Physiol Behav. 2006;87:221-44.

18. Paxinos $G$, Watson $C$. The rat brain in stereotaxic coordinates, 4 th ed. Academic Press; 1986.

19. Estadella D, Oyama LM, Bueno AA, Habitante CA, Souza GI, Ribeiro EB, et al. A palatable hyperlipidic diet causes obesity and affects brain glucose metabolism in rats. Lipids Health Dis. 2011;10:168-77.

20. Barr HG, McCracken KJ. High efficiency of energy utilization in "cafeteria"- and forced-fed rats kept at $29^{\circ} \mathrm{C}$. $\mathrm{Br} \mathrm{J}$ Nutr. 1984;51:379-87.

21. Folch J, Lees M, Sloane-Stanley GHA. A simple method for isolation and purification of total lipids from animal tissue. J Biol Chem. 1957;226:497-509.
22. Leshner AL, Litwin VA. A simple method for carcass analysis. Physiol Behav. 1972;9:282-9.

23. Goldman JK, Bernardis LL, MacKenzie RG, Kodis M, Luboshizky $R$. Effects of ventromedial hypothalamic lesions on adipose tissue of weanling male rats. Diabetologia. 1981;20:357-61.

24. Trayhurn P. Thermogenesis and energetics of pregnancy and lactation. Can J Physiol Pharmacol. 1989;67:370-5.

25. Mingrone G, Manco M, Mora ME, Guidone C, laconelli A, Gniuli $D$, et al. Influence of maternal obesity on insulin sensitivity and secretion in offspring. Diabetes Care. 2008;31:1872-6.

26. Shankar K, Kang P, Harrell A, Zhong Y, Marecki JC, Ronis MJ, et al. Maternal overweight programs insulin and adiponectin signaling in the offspring. Endocrinology. 2010;151:2577-89.

27. Bayol SA, Farrington SJ, Stickland NC. A maternal 'junk food' diet in pregnancy and lactation promotes an exacerbated taste for 'junk food' and a greater propensity for obesity in rat offspring. Br J Nutr. 2007;98:843-51.

28. Gorski JN, Dunn-Meynell AA, Levin BE. Maternal obesity increases hypothalamic leptin receptor expression and sensitivity in juvenile obesity-prone rats. Am J Physiol Regul Integr Comp Physiol. 2007;292:R1782-91.

29. Rajia S, Chen H, Morris MJ. Maternal overnutrition impacts offspring adiposity and brain appetite markers-modulation by post weaning diet. J Neuroendocrinol. 2010;22:905-14.

30. Muhlhausler BS, McMille IC, Rouzaud G, Findlay PA, Marroco EM, Rhind SM, et al. Appetite regulatory neuropeptides are expressed in the sheep hypothalamus before birth. J Neuroendocrinol. 2004;16:502-7.

31. Iossa S, Lionetti L, Mollica MP, Crescenzo R, Botta M, Barletta $A$, et al. Effect of high-fat feeding on metabolic efficiency and mitochondrial oxidative capacity in adult rats. $\mathrm{Br} \mathrm{J}$ Nutr. 2003;90:953-60.

32. Suzuki T, Hara H. Dietary fat and bile juice, but not obesity, are responsible for the increase in small intestinal permeability induced through the suppression of tigh junction protein expression in LETO and OLETF rats. Nutr Metab. 2010;7:19.

33. Rothwell NJ, Stock MJ. Energy expenditure of 'cafeteria'-fed rats determined from measurements of energy balance and indirect calorimetry. J Physiol. 1982;382:371-7.

34. Jéquier E. Pathways to obesity. Int J Obes Relat Metab Disord. 2002;26:S12-7.

35. Chlouverakis C, Bernardis LL, Hojnicki D. Ventromedial hypothalamic lesions in obese-hyperglycaemic mice (obob). Diabetologia. 1973;9:391-5. 